ŽEŇUCH, P. (ed.): Život slova v dejinách a jazykových vztahoch. Na sedemdesiatiny profesora Jána Dorulu. Bratislava, s. 265-278.

POSPÍŠIL, I. (2008a): Diachronní dimenze ruského literárního textu (Puškin - Bondarev -

Grjakalov). In: LEPILOVÁ, K. a kol.: Text a kontext. Brno, s. 86-107.

POSPÍŠIL, I. (2008b): Konzervativní rezistence jako součást literárního vývoje. Slavica litteraria, roč. 11, 2008, č. 2, s. 19-28.

POSPÍŠIL, I. (2008c): Tradiční a konzervativní hodnoty v literatuře konce zo. a počátku 21. století. In: KERULOVÁ, M. (ed.): Slovo - obraz - zvuk I. Literárnovedné štúdie. Nitra, s. 91-102.

POSPÍŠIL, I. (2009): Ponorná řeka memoárů na rozcestí. In: PAVERA, L. a kol.: Metamorfózy gatunków w kontekście środkoeuropejskim. Žánrové metamorfózy v středoevropském kontextu, sv. IV. Praha, s. 233-244.

POSPÍŠIL, I. (2010): (Zdravě?) konzervativní pojetí ruské literatury 2o. století (Kremencov Leonid Pavlovič: Russkaja literatura v XX veke. Obretenija i utraty. Učebnoje posobije. Vtoroje izdanije. Izdatel'stvo «Flinta», Izdatel'stvo «Nauka», Moskva 2oo8). Novaja rusistika, roč. 3, 2010, č. 2, s. 101-103.

POSPÍŠIL, I. (2015): Česká a slovenská próza dneška a politika: hraniční žánry (Několik př́kladů, kritických/teoretických poznámek a pokus o typologii). In: POSPÍšIL, I., PRZYBYLSKI, M., ŠAUR, J. a kol.: Slovanské literatury a jazyky v objetí politiky (20. století). Brno, s. 13-33.

POSPÍŠIL, I. (2016): Kvázimemoáry jako mentální signál (české a slovenské př́klady). In: POSPÍŠIL, I. (ed.): Poetika prózy v česko-slovenských souvislostech. Brno, s. 169-178. POSPÍŠIL, I. (2018): Valentin Rasputin glazami čechov (Portret i vokrug: neskolko štrichov). Stephanos, 2018, č. 1, s. 194-199.

Russkij literaturnyj žurnal Parus. (2018). <http://parus.ruspole.info/>. [online]. [cit. 8. 9. 2018].

SERAFIMOVA, V. D. (2013): Poetika prozy L. I. Borodina: dialog s kulturnym prostranstvom. Moskva.

https://doi.org/10.5817/NR2018-2-10

\title{
Sborník k příležitosti XVI. mezinárodního kongresu slavistů
}

POSPÍŠIL, I., ZELENKA, M., PAUČOVÁ, L. (eds): Česká slavistika 2018. Brno: Česká asociace slavistů, Jan Sojnek - Galium, 2018. ISBN 978-80-88296-oo-3.

Sborník vychází péčí České asociace slavistů ve spolupráci se Slavistickou společností Franka Wollmana a přináší příspěvky, které byly prezentovány na XVI. 
mezinárodním kongresu slavistů v Bělehradě v srpnu 2018. V úvodu informuje koeditor Ivo Pospíšil o činnosti nezávislé, metodicky tolerantní, otevřené České asociaci slavistů (ČAS), která organizuje kongresy českých slavistů s mezinárodní účastí a publikuje jejich výsledky v jednotlivých edicích. Recenzovaný svazek obsahuje 16 prací českých a slovenských slavistů a doktorandů z oblastí teorie a dějin slovanských kulturních areálů, z jazyka a literatury. Sborník jako celek je publikací hodnotnou a prínosnou jak pro studenty filologicko-areálových studií, tak pro slavistickou veřejnost. Př́ispěvky jsou v ruštině, češtině a angličtině.

$\mathrm{V}$ několika referátech je pojata problematika médií a komunikace v prostředí internetu. O vytváření vzájemných obrazů a mezikulturních stereotypů Rusů a Čechů na základě současné internetové komunikace pojednává ve svém příspěvku Jiří Gazda a dochází $\mathrm{k}$ závěru, že je třeba bojovat „proti upevňování a šíření negativních etnických stereotypů, vytvořených na základě zkušeností zprostředkovaných médií" [POSPÍŠIL, ZELENKA, PAUČOVÁ 2018, 19]. Téma současných médií nenechala chladným ani Milana Pokorného, který zkoumá „speciální roli veřejné služby“ a představuje analýzu vývoje médií veřejné služby $\mathrm{v}$ jihoslovanském areálu.

Několik článků spojuje téma poezie. Alenka Jensterle-Doležal se ve svém příspěvku zabývá poezií dvou nejviditelnějších básnířek ve slovinské moderně Vidy Jerajové a Ljudmily Poljancové, které spojovala nejenom tematika zahrnující motivy př́rody, lásky a erotiky, ale i „subjektivní pojetí reality“ vycházející „z nové senzibility" a také vytyčení „fragmentů reality a imperativu okamžiku“ [POSPÍŠIL, ZELENKA, PAUČOVÁ 2018, 21]. Simona Koryčánková pokračuje v tématu, jemuž se věnuje dlouhodobě, a ve svém př́spěvku se zabývá paralelami a podobnostmi ve filozoficky signifikantních básnických obrazech symbolistů Vladimira Solovjova a Otokara Březiny. Př́spěvek Jany Kostincové je zaměřen na současnou digitální literaturu a pojednává o způsobech existence ruské poezie $\mathrm{v}$ kontextu digitálních technologií; autorka sleduje vývoj hlavních tendencí 9o. let v kontextu 21. století, usiluje o představení cesty ruského digitálního experimentu, počínaje kolektivní interaktivní poetickou hrou 9o. let až ke transmediálnímu umění 21. století. Petr Kučera pokračuje v tématu poezie a ve svém př́spěvku s názvem Rainer Maria Rilke a česká spirituální poezie nabízí analýzu vybraných problémů oboustranné recepce básnického díla interkulturního autora a tvorby českých duchovně orientovaných básníků, $\mathrm{k}$ níž patř́ nejenom lyrika autorů z okruhu katolické moderny, ale i tvorba solitérů a také židovského básníka Jiř́ího Ortena.

Svazek obsahuje také práce komparativní, genologické a tematologické. K židovské tematice v románu slovenského prozaika Jána Tužinského Kto hodí kameňom se obrací Alexej Mikulášek a soustředuje se obzvlášṫ na koncepci židovských postav románu, na projevy antisemitismu a „vylučování. Autor př́ispěvku poukazuje především na „areál multikulturní, multikonfesijni“", na „mentální a duchovní prostor 
spolupatřičnosti, ovšem plný vnitřních rozporů “ [POSPÍŠIL, ZELENKA, PAUČOVÁ $2018,107]$. Lenka Paučová se ve svém př́ispěvku zabývá motivy čtyř živlů v Deníku spisovatele F. M. Dostojevského, srovnává je v rámci pomezních žánrů na hranici věcné a krásné literatury a hledá jejich místo v jiné spisovatelově tvorbě. „Čistotě“ žánrů $\mathrm{v}$ tištěných a elektronických textech se věnuje ve svém neméně zajímavém př́íspěvku Libor Pavera, jenž sleduje „stavbu textu elektronické komunikace a problém individuálního a kolektivního v elektronické komunikaci“ [POSPÍŠIL, ZELENKA, PAUČOVÁ 2018, 137]. Autor navrhuje provést komparaci vlastních výsledků ve studované oblasti s prŕpadnými výsledky studií ve sféře jiných druhů současného umění. $\mathrm{O}$ vlivu ruské literatury a ruské literární vědy na světový literární proces pojednává Ivo Pospíšil v prríspěvku, v němž na základě vlastní koncepce prae-post efektu se soustředuje na některé aspekty, jež měly největší význam pro vývoj literatury jako takové. Autor připomíná specifikum ruského románu a kritické hodnocení ruské sovětské literatury v pracích Alfreda Bema a význam ruských i sovětských literárních škol.

K charakteristickým rysům literárněkritických prací dnes spíše méně známého, ale ve své době významného ruského literárního kritika, historika literatury a memoáristy P. V. Anněnkova se vyjadřuje ve svém př́spěvku Josef Šaur a poukazuje na to, že autor při hodnocení literárních děl kladl důraz nikoli pouze na estetickou stránku, ale „také na harmonii a mravní hledisko“ [POSPÍŠIL, ZELENKA, PAUČOVÁ 2018, 179], což mění pohled na Anněnkova jako literárního kritika a na jeho estetické a umělecké postoje. Autor př́spěvku zdůrazňuje nutnost hledání vlivů evropského liberalismu $\mathrm{v}$ ruském prostředí i mimo politickou sféru.

Tématu ruské literárněvědné emigrace v meziválečném Československu se věnuje Miloš Zelenka, jenž se ve svém př́spěvku opírá o dosud nepublikované archivní zdroje a dochází $\mathrm{k}$ závěru, že jím předložené různé kulturní modely v jejich vzájemném spojení a vzájemném doplnění můžou pomoci zcela pochopit složitý fenomén ruské vědecké emigrace. $\mathrm{O}$ folkloristické práci (moravských sběrech) zakladatele brněnské slavistiky Franka Wollmana pojednává Anna Zelenková, která analyzuje jeho názory nejenom jako literárního vědce, ale i jako teoretika folkloru „na podstatu folkloru a jeho významný přínos $\mathrm{v}$ oblasti sběru slovenské a moravské lidové slovesnosti v meziválečném obdobi“" [POSPÍŠIL, ZELENKA, PAUČOVÁ 2018, 199].

Eva Kudrjavceva Malenová se dlouhodobě věnuje problematice vývoje a recepce ruské dětské literatury v českém a středoevropském kontextu a také překladu ruských pohádek. Ve svém př́spěvku se zabývá vlivem sametové revoluce na české překlady ruské literatury pro děti a představuje výsledky bádání z historie českých překladů ruské dětské literatury v druhé polovině 20 . - začátku 21. století.

Otázky lingvistiky, konkrétně tendence $\mathrm{k}$ jazykovému analytismu ve slovanských jazycích, jsou ve středu pozornosti Jindřicha Kesnera, který ve svém prŕíspěvku 
pojednává o proniknutí prívlastků vyjádřených nesklonným prepozičním adjektivem do současného jazyka, uvádí různé způsoby klasifikace daných jazykových útvarů a porovnává jejich vznik a použití v současném ruském a českém jazyce.

Giuseppe Maiello se ve svém př́spěvku zabývá italskou koncepcí českého národního obrození a klade si otázku o možných př́ícinách „slabšího zájmu ze strany Itálie o tento důležitý moment českých dějin“ [POSPÍŠIL, ZELENKA, PAUČOVÁ 2018, 95].

Je patrné, že jednotlivé příspěvky sborníku jsou vzájemně propojené a zahrnují nejenom tradice, $\mathrm{z}$ nichž vychází česká slavistika, ale také poměrně nové jevy a tendence, které souvisí s novými technologiemi, obsahují též široké srovnávací studie stavu a dynamiky vývoje jazyka a literatury a jejich politické aspekty v prostoru slovanských kultur.

Tatjana Zaňko

\section{Literatura:}

POSPÍŠIL, I., ZELENKA, M., PAUČOVÁ, L. (2018) (eds): Česká slavistika 2018. Brno.

\section{Další svazek brněnské slavistiky ke střední Evropě}

POSPÍŠIL, I. (ed.): Střední Evropa včera a dnes: proměny koncepcí II. Brno: Středoevropské centrum slovanských studií, Jan Sojnek - Galium 2018. ISBN 978-80-88296-01-0.

Kolektivní publikace obsahuje materiály stejnojmenné mezinárodní vědecké konference, jež proběhla v půlce listopadu roku 2017 ve spolupráci Středoevropského centra slovanských studií a České asociace slavistů s Ústavem slavistiky FF MU a Slavistickou společností Franka Wollmana a je pokračováním tradice brněnských konferencí o střední Evropě. Rozsáhlý svazek plynule navazuje na jeho první část Střední Evropa včera a dnes: proměny koncepcí a je monografickou analýzou různých aspektů a konkrétním výzkumem jevů střední Evropy. Sborník je zdařilým pokusem o objasnění role a místa stř̌ední Evropy v dnešním evropském myšlení a také o vystižení hodnocení vývoje střední Evropy v posledních desetiletích. V úvodu editor monografie Ivo Pospíšil zmiňuje fenomén střední Evropy, která je spíše duchovním nežli geopolitickým prostorem, areálem. Publikace ve 36 př́spěvcích českých, polských, slovenských, madarských, ukrajinských, ruských a slovinských autorů svým způsobem 